\title{
An Assessment of the Linkage between Financial Reporting and Taxation in Tunisia
}

\author{
Wiem Dridi ${ }^{1} \&$ Adel Boubaker ${ }^{1}$ \\ ${ }^{1}$ Université de Tunis El Manar, International Finance Group Tunisia, Tunisia \\ Correspondence: Wiem Dridi, PhD Student, Faculty of Management and Economic Sciences of Tunis, \\ Université de Tunis El Manar, Tunisia. E-mail: wiembououni@gmail.com
}

Received: November 7, 2014

Accepted: March 9, 2015

Online Published: March 25, 2015

doi:10.5539/ibr.v8n4p168

URL: http://dx.doi.org/10.5539/ibr.v8n4p168

\begin{abstract}
The relationship between tax and financial reporting has deferred widely over time. The connection between accounting and taxation can provide negative effects; such as earnings management for fiscal purposes and value relevance distortion. This leads to an optimal and efficient looking on the nature of the relation that should bring them together. Few studies have focused on this relationship in some countries, but no research has been applied in the context of Tunisia using an empirical model. In this paper, we analyze within this framework the Tunisian case. We specified a longitudinal dimension of tax and financial reporting association through the separation of two periods of evolution. We collected information about the different accounting and fiscal treatments of seventeen substantial accounting topics from 1968 to 2013, and we assessed them using five cases of connection or disconnection. The results show that even in the case of the lack of accounting standards, there is a total disconnection between accounting and taxation in Tunisia. We also found that the relationship between accounting and taxation in this country was a typical of continental European countries before accounting normalization. After the Tunisian accounting system implementation, the nature of this relationship has changed to the Anglo-Saxon system.
\end{abstract}

Keywords: accounting, taxation, Tunisia

\section{Introduction}

Several studies show that the relationship between accounting and taxation has changed over time (Hoodgendoorn, 1996; Nobes et al., 1992; Lamb et al., 1998; Oliveras \& Puig, 2007; Gallego, 2004; Shaviro, 2009; Haller, 1992). This relationship can generate negative effects (such as accounting manipulation for fiscal purposes). This leads to an optimal and efficient looking on the nature of the relation that should bring them together. Specifying the nature of this relationship is very important especially for investors. Epps and Oh (1997) show that, at the announcement of the earnings of foreign companies, US investors react more when these firms are located in Anglo-Saxon countries than when these are located in continental countries (where the accounting system is used more for tax requirements). Many studies have examined this area in various countries (Aisbitt, 2002; Blake et al., 1993, Blake et al., 1997; Rossignol, 1999; Rossignol, 2002; Whitaker, 2005; Nobes, 2004; Formigioni, 2009) which have different approach regarding this relationship. In continental countries, Haller (1992) and Radcliffe (1993) found that accounting is considered as an instrument of taxation which implies a strong correlation between both.

The degree of connection between the accounting and tax system can be influenced by different factors including the purpose of each of them. Tax meets the needs of government. However, the accounting system is designed for financial information reasons. The purpose of each system leads to a gap between the pre-tax income and the taxable income (book-tax differences). This difference is used as a proxy for earnings management (Joos et al., 2000; Mills \& Newberry, 2001; Donohoe \& McGill, 2010; Comprix et al., 2011, Hanlon, 2005; Blaylock et al., 2012) or tax planning (Wilson, 2009). Some studies attribute the book-tax differences to both earnings and tax management (Tang \& Firth, 2011; Tang \& Firth, 2012; Chen et al., 2012). Despite this difference, there is a strong link between tax and accounting, which dates back to the origin of the earliest civilizations. Lamb (2009) reveals that stories of taxation and accounting are closely related. The common basis of accounting and taxation, as well as their common changes, produce a mutual development of standardization that regulates these systems. Hoogendoorn (1996) notes that the relationship between accounting and taxation is moving. The proposed 
changes in this relationship tend to move towards independence since the economies of these countries are moving towards the market economy. Aisbitt (2002) reports that one on the main reasons for the separation of accounting and taxation consists in improving international comparability of financial statement but it is hard to believe in a complete independence. More recently, Eberhartinger and Klostermann (2007) investigated the relationship between taxation and international standards. Alley and James (2006) argued that accounting and taxation are in a process of continuous development.

In this context, the ex-colonial countries such as Tunisia have experienced successive phases of development in the political system over the two past decades, which is one of the most important factors that influence regulations, standards and accounting practices (Radebaugh, 1975) and taxation. Our study is part of the research on the relationship between accounting and taxation which has always influenced the direction of many countries in the regulation of these two systems (including the adoption of international standards which leads to a clear separation of taxation and accounting). Our contribution lies in the application of an approach to determine the nature of the relationship between accounting and taxation in the Tunisian case. At the international level, numerous studies have been concluding about this issue. However, to our knowledge no study has established an empirical study to examine this relationship in national studies. Our study contributes to the literature by providing clear evidence about the link between accounting and taxation.

Following Lamb et al. (1998) and Nobes and Schwencke (2006), we specified a longitudinal dimension of the link through the highlighted intervals period of evolution in Tunisia. We then adopted the 15 items used by Lamb et al. (1998) and two new topics supplemented the latter list by Nobes and Schwencke (2006) "Impairment" and "Financial assets" to identify the differences in the treatment between accounting and taxation. Gee et al (2010) added the topic of share-based payment but we ignored this item as Micallef (2011). The rationale is that financial participation of employees and managers are not widely recognized in Tunisia. These 17 elements will be classified into five cases according to Lamb et al. (1998) and Nobes and Schwencke (2006).

The choice of approach Lamb et al. (1998) can be firstly explained by its efficiency since it allows presenting an analysis of certain items in accounting and tax terms. Moreover, this approach has been adopted by a number of researchers who have applied this in different countries, regardless of their history (Spain, Norway, Romania, Italy, Malaysia, Japan, Malta, Australia) or membership (continental and Anglo-Saxon countries) (Nobes \& Schwencke, 2006; Oliveras \& Puig, 2005; Azmi, 2008; Gavana et al., 2013; Micallef, 2011).

This approach can be applied in Tunisia for two reasons: Tunisia has a long history as suggested by Nobes and Schwencke (2006, p. 67) as a condition for the application of their approach. In addition, political and social changes data in the Eighties has facilitated the distribution of events that can change the tax-accounting link. This system was borrowed before independence from the continental to an Anglo-Saxon system. Similarly, the tax system has not been immune of alterations and changes in codes and rules, which is still an object of proliferation and rectification. We hypothesize that in the absence of an accounting standard, the tax rule dominates. Moreover, the accounting standard leads to independence between accounting and taxation.

To test our hypotheses, we collected information about the different accounting and fiscal treatments of these 17 items from the period from 1968 to 2013. Our results show that there is a disconnection rather than fiscal influence, which disproves our first hypothesis. Consistent with our second hypothesis, the results indicate that disconnection between accounting and taxation increases after the enactment of the new accounting system. This implies that despite the use of accounting as a tax base, each system has its own rules which lead to a significant difference between these two disciplines. Our results contribute to the broader debate on the use of these differences for manipulation purposes in order to achieve desired objectives. This study helps to understand the main source of earnings management and fiscal management; therefore it allows a better understanding of book tax differences.

The paper proceeds as follows: Section 2 describes the accounting and taxation report in the Tunisian context; Section 3 describes the research method; Section 4 presents the assessing results; Section 5 discusses the results and Section 6 concludes the paper.

\section{Institutional Background in Tunisia and Hypotheses Development}

In the late 80s, the Tunisian tax system underwent a significant transformation. Being characterized by its complexity and high tax rates, the tax system was unfair. There was an injustice between taxpayers; some suffered from tax burden while others benefited from the advantages and exemptions even though they made huge revenues. The tax burden was around $24 \%$ in 1983, so it was necessary to intervene in the legislative plan to resolve these deficiencies. Especially, since the high burden of tax has led to the emergency of certain practices of tax evasion, and a set of exemptions of certain sectors. 
In this context, legislature has introduced a new tax expenses (Value Added Tax) by Law No. 88-61 of 2 June 1988 applied the value added tax code and Law 88-62 of 2 June 1988 overhaul of consumer law. Law No. 88-114 of 30 December 1988 makes a change in the tax code on personal and corporate income tax. This law introduced a single tax on income of physical persons and a single income tax companies. This tax replaced the former system based on double taxation at the schedule. This reform was followed by the enactment of Law No. 93-53 of 17 May 1993 relating to the code of registration fees and stamp duty. The legislature intervened by Law No. 93-120 of 27 December 1993 modifying the Investment Incentives Code. Finally, local finances have been organized by the Law 97-11 of 3 February 1997, of the code of local taxation.

The Tunisian accounting regulation is governed by the Corporate Accounting System (CAS), which embodied in the accounting and finance since 1997. This system was the result of an ideological accounting changes started by General Accounting Plan of 1968 inspired by the French Plan from 1947 and 1957. The Tunisian accounting system was based on accounting plan dating back to 1968. It has undergone a reform by Law No. 96-112. The concern of the Tunisian legislator is to meet the needs of investors. The adoption of a new accounting system borrowed from the Anglo-Saxon system has remedied its predecessor based on the continental European model. The relationship between accounting and taxation has been a shifted towards independence. In fact, the previous GAAP draws its concepts of taxation system. The adoption of Law No. 69-112 created a conceptual autonomy of accounting; accounting is a fully fledged legal branch. It comes now of a legal based rule who own these concepts and notions (Ben Othman \& Zéghal, 2006).

However, the independence between accounting and tax rules is not absolute. Accounting practices revealed a connection between the accounting and other laws, including the tax system. For example the 96-112 law does not determine income distribution. In addition, Article 30 of the Tax Code on personal and corporate income tax was used to define this concept.

Moreover, taxation is mainly based on accounting. Taxable income is determined through the restatement of the net income. Thus, we test two hypotheses:

H1: In the absence of accounting standard, the tax rule dominates.

H2: The accounting standard leads to independence between accounting and taxation.

\section{Research Method}

As mentioned above, Lamb et al. (1998) hold a nomenclature of fifteen items for which they proposed to recognize the differences between the accounting and tax treatment. These authors suggested identifying five categories of possible relationship between accounting and taxation. The first category is a disconnection, the second is an identity, the third accounting leads, taxation leads in the fourth case and taxation dominates for the last case. Based on this classification, the authors applied their method on four countries, two countries belonging to the Anglo-Saxon system (United Kingdom and United States) and two of the continental European system (France and Germany). Nobes and Schwencke (2006) continued the Lamb et al. (2008) approach by applying it in the Norwegian case; these authors presented six different cases (Table 1). In fact, case III was divided by Nobes and Schwencke (2006) into two sub-cases, sub-case III and sub-case III'. Sub-case III 'when the accounting prevails. In addition, Nobes and Schwenke introduced the longitudinal development of the connection between accounting and taxation as a new dimension in this relationship. They identified successive stages of this evolution. We adopt the methodology of Lamb et al. (1998) modified by Nobes and Schwencke (2006). We evaluated topics, used by those authors (17 topics: 20 scores in all, including sub-topics), through their classification in five categories (based on the level of connection between accounting and taxation). Then, we adopted these elements to the Tunisian context by making changes (we divided subsidies into two categories because each has its own treatment.)

The assessment of topics necessitates the analysis of accounting and taxation regulations. As Lamb et al. (1998), this classification is done in a subjective way, as is done by our own professional judgment. We also selected individual accounts as a basis for analyzing because they represent the majority of the population. We chose the period of study from 1968 (date of the first accounting plan in Tunisia) to the date of Tunisian accounting system enactment. We separated the analysis period into two periods: before 1997 (date of Tunisian accounting system enactment) and after 1997 in order to detect the influence of taxation on accounting. 
Table 1. Cases of connection between accounting and taxation by Lamb et al. (1998) modified by Nobes and Schewenke (2006)

\begin{tabular}{lll}
\hline Case & Relation & Description \\
\hline I & Disconnection & The rules governing the taxation and accounting are different and are designed for different purposes. \\
II & Identity (Total connection) & Identity between tax and accounting rules. \\
III & Accounting leads & The accounting rules are used for accounting and tax purposes due to the lack of tax rules \\
III' $\quad \begin{array}{lll}\text { Accounting leads } \\
\text { "reverse effect" }\end{array}$ & $\begin{array}{l}\text { Accounting standards recommend rules to reduce or defer income. These standards may be subject for } \\
\text { tax optimization for the absence of a specific tax rule. } \\
\text { IV }\end{array} \quad$ Taxation leads & The tax rule is adopted in accounting \\
V & Taxation dominates & The tax rule is used for tax and accounting purposes, even in the presence of accounting rules
\end{tabular}

\section{Assessing Results}

\section{Topic 1: Fixed asset measurement}

Revaluation was absent in the accounting plan of 1968; which retained a simple explanation of the 'renewal reserves' account. Since 1997, accounting standards relating to tangible and intangible assets has retained the principle of revaluation of assets; these standards indicate that revaluation concerns only the case of value reduction. This provision preserves the historical cost as the rule of fixed assets recognition. Therefore, any upward revaluation of the assets, does not comply with the provisions of Tunisian Accounting Standards (This rule is opposed to international accounting standards that allow the upward revaluation of fixed assets). On the fiscal side, the revaluation has been set by law through the principle of "balance sheet revaluation" which was retained by the patent code since 1895. Thus, the new tax system in 1989 has not made any changes on this point. This recognition of the tax reassessment identifies domination of the tax rule in the period before 1997. This is CASE V: taxation domination.

From 2000, the statutory revaluation has been abolished by Article 30 of the Finance Act 2000 and the companies proceed now to the free revaluation (without legal framework). However, the tax doctrine specifies that the accounting recognition of the upward free revaluation of the assets is not considered on taxable income. We see the transition, from 2000, from CASE V to CASE III: accounting leads.

\section{Topic 2. Impairments}

The accounting plan of 1968 considers that impairments are included in assets deducted from accounts subject to valuation. Similarly, the accounting system allows provision when the reduction is considered to be permanent. If the impairment is reversible, it is recognized as an expense by reducing the gross value of the asset. In both cases, the reduction in value rather than depreciation is not deductible for tax purposes and shall be reinstated to income for the year in which it is recognized. This is a disconnection, CASE I.

\section{Topic 3. Lease classification}

Leasing contracts came into force in 1984 (date of creation of the first leasing company). The deduction for depreciation was not allowed in the case of assets acquired through leasing contracts; this is the principle of 'balance sheet patrimoniality'. CASE IV reflects the fact: taxation leads. Under the Tunisian conceptual framework (1997), the property subject to a lease must be counted as fixed assets and recognized as an expense through depreciation. Charges for leasing contracts were considered deductible from taxable income as rental expense. This is CASE I: disconnection. Law $n^{\circ} 2007-70$ of 27/12/2007, concerning finance law for 2008, adopted the method used by the accounting system. It suggests the CASE II: identity.

\section{Topic 4. Depreciation}

Since 1968, the accounting rule has recognized the economic conception in depreciation recognition. However, the tax regulations have adopted the normal method (across rates set by law). Companies can make also, excess depreciation for equipment which useful life exceeds seven years (under straight-line depreciation method). This is the CASE I: disconnection. In 2007, tax rule changed; depreciation was deductible from the tax base according to the accounting recognition. This topic has become a CASE II: identity.

\section{Topic 5. Contingencies, provisions}

Since 1968, accounting has recommended any provisions for impairments and provisions for losses and expenses. 
Tax regulations have claimed that allowance for risk and expense is not deductible from the tax base. As for the impairment, the tax deduction legislator allows only, three types of provisions and in specific cases. Thus, there is a complete separation between the accounting and tax regulations. This is CASE I: disconnection.

\section{Topic 6. Subsidie}

1) Investment Subsidies or equipment.

Prior to 1997, accounting policy is differentiated from the tax rule. This is the CASE I: disconnection. After 1997, an identity is estimated between accounting rules and tax rules if the grant is amortizable, this is a CASE II: identity. When the purpose of the grant is not depreciable, it is a CASE I: disconnection.

2) Operating Subsidies.

Prior to 1997, there was no clear accounting rule, it was estimated that the tax rule leads. This was a CASE VI: taxation leads. After 1997, accounting regulation required a separate rule of taxation. This is a disconnection between taxation and accounting. This topic has become a CASE I: disconnection.

\section{Topic 7. Research and development costs}

The 1968 accounting plan allowed accounts for research and development costs. The tax code did not establish provision relating to this topic and has no dedicated none tax treatment of expenses related to these activities. In case of applying the principle of "autonomy to resolve differences between accounting and tax accounting", the accounting leads, but this time with a reverse effect. This is CASE III': Accounting leads with "reverse effect". In 1999, a new accounting standard was implanted, it is always the CASE III': Accounting leads with "reverse effect". However, this rule is not always valid. Accounting regulation sometimes requires a particular treatment relating to the value reduction. The expenses related to this reduction are not deductible of tax base. We can see that the CASE III' can sometimes be CASE I: disconnection.

In 2007, the tax law repealed the non-deduction of amortization of patents and brand. Similarly, depreciation related to license fees is now deductible from the tax base. These measures have altered the relationship between accounting and taxation; this is the CASE I: identity.

\section{Topic 8. Inventory valuation}

The inventory valuation has not changed since accounting plan in 1968. Inventories are valued at historical cost or net realizable value. According to Article 11 of the tax Code, inventories are recognized at cost price. Taxation and accounting disconnect. This was CASE I.

At the end of the year, the company evaluates its stock and recognizes a provision in the case of impairment. If impairment is irreversible, the firm recognizes a loss (637 - value reduction). Fiscally, irreversible depreciation is not deductible. Moreover, the inventory depreciation should not exceed $50 \%$ of the cost price and a ceiling of $50 \%$ of taxable income (Article 12 of the Tax Code). This is a disconnection between the tax and accounting. It stills the CASE I.

\section{Topic 9. Long-term contracts}

The 1968 accounting plan did not address goods and work in progress. On the fiscal side, services must be recorded among income in accordance with the principle of "exercises specialization" of accounting standard. This is CASE IV: taxation leads. Since 1997, accounting regulation specifies that income can be recognized using the percentage of completion basis. This is CASE II: identity. From 2003, the administrative doctrine has adopted a different treatment; the unfinished work must be recorded in an inventory account of services. This topic has become a CASE I. However, in some special cases, the accounting standard admits the possibility of taking some services in the inventory account. This makes us think that the CASE I: disconnection can sometimes be CASE II: identity.

\section{Topic 10. Interest expense}

\section{1) Capitalization of Interest}

In accounting, interest expense is imputed in the cost price of the property subject of the loan; it is not the case of an expenses capitalization (which is prohibited by the tax rule). In fact, these costs are part of the cost price. The tax legislation does not define the composition of the cost price; tax legislation is not specific. Therefore, we can conclude that the taxation follows accounting. CASE III: Accounting leads.

2) Other

The accounting standard relating to borrowing expenses specifies that, borrowing expenses are interest and other 
expenses related to the borrowing of funds. According to paragraph three of the same standard, they must be recorded in the fiscal year in which they are incurred. Under the general rules of deduction, the loan must be designed for the operation and included in accounting. Therefore, if the loan was used for the individual account of the operator, interest expense will be reinstated. This is the CASE I: disconnection.

\section{Topic 11. Financial assets}

Until 1997, accounting legislation has not defined the listed securities since the Stock exchange in Tunisia was established in 1969. This was CASE IV: taxation leads. After approval of the accounting system, the standard specified that the financial assets are recorded according to the cost of acquisition. The tax rule took the same direction as accounting for input value of financial assets. CASE II: identity.

\section{Topic 12. Foreign currency transaction}

At the completion date, accounting and taxation follow the same rule (the exchange rate difference between the recorded at the completion of the transaction and the amount actually paid amount is a gain or loss in the income exercise). This is CASE II: identity. At the closing of the year, the Tunisian accounting standard requires the assessment of assets and liabilities in foreign currencies at each balance sheet date using the exchange rate in effect on that date. The result of the exercise takes thus into account the gain or loss. However, the gain or loss recognized is not deductible for tax purposes as the receipt or payment of the debt has not occurred. This is the CASE I: disconnection.

\section{Topic 13. Purchased goodwill}

Taxation code does not allow the deduction of amortization of goodwill from taxable income. The accounting plan of 1968 allowed the depreciation relative to its economic value without regardless of its fiscal or legal nature. This is the CASE I: disconnection. After 1997, the accounting standard has required that goodwill and leasehold rights are amortized over a period not exceeding 20 years. It is always the CASE I.

\section{Topic 14. Pensions}

Social contributions related to the responsibility of the employer for pensions and insurance group are part of the compensation paid or payable to employees. These expenses are deductible because they correspond to an effective working related to the service rendered. This tax rule is consistent with the accounting rule. This is CASE II: identity.

\section{Topic 15. Policy changes and fundamental errors}

The accounting plan of 1968 did not allow a better estimate of forms, treatments and procedures of different modifications that can be recorded. New accounting system had to be enacted to learn about the treatment of changes in accounting methods, the correction of fundamental errors and estimates changes.

1) Change in accounting methods

The accounting standard relating to accounting changes provides two types of application of the change in accounting methods: A retrospective and a prospective application. We may judge that accounting dominates tax because taxation rule depends on the date of consideration of the change in accounting treatment method; this is CASE III': Accounting leads with "reverse effect".

\section{2) Estimates changes}

The estimates changes for the current year are recognized in income or expense of that year. This treatment is approved by the administration which considers these changes in estimates like affecting the income and expenses. These changes in estimates are treated according to the same rules as other income and expenses. It is CASE II: identity

\section{3) Correction of fundamental errors}

The amount of the correction of a fundamental error detected in the previous financial statements shall be recognized in equity of the opening. These errors are treated for tax purposes under the rule of the "symmetric correction". It is an identity between accounting and taxation. This is CASE II: identity.

\section{Topic 16. Scope of the group}

In Tunisia, it is the Accounting Act No. 96-112 of 30 December 1996 which required the preparation and publication of consolidated accounts in the manner prescribed by the accounting standards on consolidation. Meanwhile, Tunisian legislation recognized the concept of group through section 30 of the Finance Act for the management in 2001. The law advocated the tax consolidation regime results, allowing compensation between 
beneficiary and deficit results among companies under certain conditions results. Subsequently sections 17,18 and 20 of the Finance Act 2004 have introduced other measures to the flexibility of this rule. Accounting and taxation identify. CASE II: identity.

\section{Topic 17. Fines, charitable donations, entertaining, expenses}

These expenses are considered in accounting as charge of operation. In taxation rule, expenditures that do not have a direct counterpart on current operations are considered as abnormal management which is an act that deprives them of the deduction. However, this principle is not always valid. There is a disconnection between taxation and accounting. This is CASE I: disconnection.

Table 2. Areas of linkage between tax and financial reporting in Tunisia

\begin{tabular}{|c|c|c|c|c|c|}
\hline & Areas & $1997-$ & -1997 & 2013 & \\
\hline 1 & Fixed asset measurement. & $\mathrm{V}$ & V then III & III & \\
\hline 2 & Impairments & I & I & I & \\
\hline 3 & Lease classification & IV & I then II & II & \\
\hline 4 & Depreciation & I & I then II & II & \\
\hline 5 & Contingencies, provisions & I & I & I & \\
\hline \multirow[t]{3}{*}{6} & Subsidie & & & & \\
\hline & -Investment & I & II sometimes I & II sometimes I & \\
\hline & -Opération & IV & I & I & \\
\hline 7 & Research and development costs & III' & III' then I & I & \\
\hline \multirow[t]{3}{*}{8} & Inventory valuation & & & & \\
\hline & -Cost measurement & I & I & I & \\
\hline & -Other areas (e.g. impairement) & I & I & I & \\
\hline 9 & Long-term contracts & IV & II sometimes I & II sometimes I & I \\
\hline \multirow[t]{3}{*}{10} & Interest expense & & & & \\
\hline & -Capitalisation & III & III & III & \\
\hline & -Other & I & I & I & \\
\hline 11 & Financial assets & IV & II & II & \\
\hline 12 & Foreign currency transactions & II sometimes I & II sometimes I & II sometimes & I \\
\hline 13 & purchased goodwill & I & I & I & \\
\hline 14 & Pensions & II & II & II & \\
\hline 15 & Policy changes and fundamental errors & II & III' sometimes II & III' sometimes & II \\
\hline 16 & Scope of the group & - & II & II & \\
\hline 17 & Fines, charitable donations, entertaining, expenses & I & I & I & \\
\hline
\end{tabular}

\section{Interpretation of Tunisia Accounting-Fiscal Links and International Comparison}

Our study is one of studies that seek to identify the link between accounting and taxation. Like continental European countries, the determination of taxable income in Tunisia, has always relied on the accounting system. In our data, we have supported the fifteen topics in Lamb et al. (1998) supplemented by two others (impairment and financial assets) introduced in Nobes and Schwencke (2006). These elements are summarized in Table 2. The following Table 3 translates the relationship between accounting and taxation in two columns for Tunisia before and after normalization.

Following Nobes and Schwencke (2006) we have separated CASE III and CASE III' in order to identify the potential tax influence on financial reporting. Then, we have assessed the tax influence by the two measures of tax influence used by Nobes and Schwencke (2006). The excess of CASEs IV and V over CASE I represents the 
minimum of tax influence and the excess of CASEs III', IV and V over CASE I reflect the maximum influence of taxation.

These indices of the minimum and maximum taxation impact on accounting revealed a remarkable disconnection. In fact, the indices is largely negative in all periods, these signs show that the case of a disconnection is present rather than a fiscal influence on accounting. This result leads us to reject our first hypothesis. This disconnection is growing and is confirmed after the implementation of the new accounting system, which confirms the hypothesis of independence between the two regulations after accounting system approval in 1997. Table 3 shows that CASE I and CASE II includes the most accounting topics. This suggests that taxation and financial reporting have their own purposes and regulations. After 1997, the number of disconnections and identities (CASEs I and II) increased to the detriment of CASEs III', IV and V which shows that tax law gives more liberty to the accounting rules and the tax effect decreases.

From an international comparison based on Lamb et al. (1998) study, we have also observed in Table (3), that the Tunisian tax-accounting relation has a mutation from a continental European system (France and Germany) before accounting system enactment to the Anglo-Saxon system (USA and UK) which proves the will of the Tunisian accounting standard setter to move closer to the international standards to facilitate the integration of Tunisian companies to IFRS.

Table 3. International comparison of linkages

\begin{tabular}{|c|c|c|c|c|c|c|}
\hline & Germany & France & Tunisia & Tunisia & USA & UK \\
\hline & 1996 & 1996 & -1997 & 1997- & 1996 & 1996 \\
\hline Disconnection: I & 2 & 4.5 & 9.5 & 11 & 13.5 & 14 \\
\hline Identity: II & 0 & 5 & 2.5 & 6 & 2.5 & 2 \\
\hline Accounting Leads: III & 5.5 & 3.5 & 1 & 1.5 & 1 & 1 \\
\hline Accounting Leads: III' & 2 & 1 & 1 & 1 & 1 & 2 \\
\hline Tax Leads: IV & 7.5 & 5 & 4 & $\mathbf{0}$ & 1 & 0 \\
\hline Tax Dominates: V & 3 & 1 & 1 & 0.5 & 0 & 0 \\
\hline \multirow[t]{2}{*}{ N.A. } & 0 & 0 & 1 & $\mathbf{0}$ & 1 & 1 \\
\hline & 20 & 20 & 20 & 20 & 20 & 20 \\
\hline Minimum Index (Case IV/V-Case I) & +8.5 & +1.5 & -4.5 & -10.5 & -12.5 & -14 \\
\hline Maximum Index (Case III'/IV/V-Case I) & 10.5 & +2.5 & -3.5 & -9.5 & -11.5 & -12 \\
\hline
\end{tabular}

\section{Conclusion and Discussion}

This paper examines the association between accounting and taxation in the case of Tunisian. The detection of this relationship for each country has become crucial in the wake of recent accounting scandals. We specifically investigated tax influence before and after accounting normalization through a significant list of items that show the differences in treatment between the accounting rules and tax law. We investigated throughout an extended period for a better assessment of the evolution of the relationship between accounting and taxation. Accounting and tax regulations have deferred widely over this period (see Appendix. A). We found that even in the case of the lack of accounting standards there is a total disconnection between accounting and taxation. We also found that accounting standards leads to more independence between these two fields. This paper also shows that the relationship between accounting and taxation was typical of continental European countries before accounting normalization and it has changed to Anglo-Saxon system after Tunisian accounting system implementation. The disconnection remains the prevailing feature of the link between accounting and taxation.

However, there are some limitations to this work. The first limitation is the total absence of empirical research addressing the relationship between accounting and taxation in the case of Tunisia in order to make a comparison between the results. The second limitation relates to our refrain to introduce a new element concerning the Tunisian context. We found that elements introduced by Lamb et al. (1998) and Nobes and Schwencke (2006) are fairly sufficient and substantial. Therefore, we chose to keep the same elements in order to make a comparison with the results of their research. The introduction of a new element will prevent as to any possibility 
of assimilation.

This paper allows some interesting research paths. This study did not investigate the connection degree between the Tunisian accounting system and international standards. It will be of further interest to place the Tunisian accounting model compared to IFRS (International Financial Reporting Standards) in order to investigate the likely harmonization. Likewise, it will be beneficial to study the impact of taxation on the potential adoption of IFRS. We also suggest studying the impact of the relationship between accounting and taxation looking at the gap between the pre-tax income and the taxable income. Such a disconnection can provides a favorable ground for manager to engage in earnings manipulations.

\section{References}

Aisbitt, S. (2002). Tax and accounting rules: Some recent developments. European Business Review, 14(2), 92-97. http://dx.doi.org/10.1108/09555340210420064

Alley, C., \& James, S. (2006). The use of financial reporting standards-based accounting for the preparation of tax returns. International Tax Journal, 31(3), 31-48.

Azmi, A. (2008). The relationship between taxation and financial reporting: The case of Malaysia. The Business Review Cambridge, 10(1), 96-103.

Ben Othman, H., \& Zéghal, D. (2006). Analyse des déterminants de la gestion des résultants: Cas des firmes canadiennes, françaises et tunisiennes. Comptabilité, contrôle, audit et Institution(s). $27^{\text {ème }}$ congrès de l'AFC Tunisie. Retrieved from https://halshs.archives-ouvertes.fr/halshs-00581061

Blake, J., Akerfeldt, K., Fortes, H., \& Gowthorpe, C. (1997). The relationship between tax and accounting rules: The Swedish case. European Business Review, 97(2), 85-91. http//dx.doi.org/10.1108/09555349710162599

Blake, J., Amat, O., \& Fortes, H. (1993). The relationship between tax regulations and financial accounting: A comparison of Germany, Spain and the United Kindom. Working Paper, Retrieved from http://www.econ.upf.edu/docs/papers/downloads/46.pdf

Blaylock, B., Shevlin, T., \& Wilson, R. (2012). Tax avoidance, large positive book-tax differences, and earnings persistence. The Accounting Review, 87, 91-120. http://dx.doi.org/10.2308/accr-10158

Chen, L. H., Dhaliwal, D. S., \& Trombley, M. A. (2012). Consistency of book-tax differences and information content of earnings. The Journal of American Taxation Association, 34(2), 93-116. http://dx.doi.org/10.2139/ssrn.2032593

Comprix, J., Graham, R., \& Moore, J. (2011). Empirical evidence on the impact of book-tax differences on divergence of opinion among investors. Journal of the American Taxation Association, 33(1), 51-78. http://dx.doi.org/10.2308/jata.2011.33.1.51

Donohoe, M. P., \& McGill, G. A. (2010). The effects of increased book-tax differences tax returs disclosures on firm valuation and behavior. Journal of American Taxation Association, 33(2), 35-65. http://dx.doi.org/10.2308/atax-10056

Eberhartinger, E., \& Klostermann, M. (2007). What if IFRS were a tax base? New empirical evidence from an Austrian perspective. Accounting in Europe, 4, 141-168. http://dx.doi.org/10.1080/17449480701727932

Epps, R. W., \& Oh, J. W. (1997). Market perception of foreign reports: Differential earnings response coefficients between U.S. and foreign GAAP. Journal of International Accounting Auditing and Taxation, 6, 49-74. http://dx.doi.org/doi:10.1016/S1061-9518(97)90012-4

Ezzamel, M. (2009). Order and Accounting as a performative ritual: Evidence from ancient Egypt. Accounting, Organizations and Society, 34, 348-380. http://dx.doi.org/doi:10.1016/j.aos.2008.07.004

Formigioni, H., Antunes, M. T. P., \& Paulo, E. (2009). Difference between accounting profit and taxable profit: An analysis of management of accounting results and tax management at Brazilian public companies. Brazilian Business Review, 6(1), 42-58. http://dx.doi.org/10.15728/bbr.2009.6.1.3

Gallego, I. (2004). Difference between accounting profit and taxable profit. Managerial Auditing Journal, 19(6), 796-819. http://dx.doi.org/10.1108/02686900410543903

Gavana, G., Guggiola, G., \& Marenzi, A. (2013). Evolving connections between tax and financial reporting in Italy. Accounting in Europe, 10(1), 43-70. http://dx.doi.org/10.1080/17449480.2013.774733

Gee, M., Haller, A., \& Nobes, C. (2010). The influence of tax on IFRS consolidated statements: The convergence of Germany and the UK. Accounting in Europe, 7(1), 97-122. 
http://dx.doi.org/10.1080/17449480.2010.485382

Haller, A. (1992). The relationship of financial and tax accounting in Germany: A major reason for accounting disharmony in Europe. International Journal of Accounting, 7, 10-23.

Hanlon, M. (2005). The persistence and pricing of earnings, accruals, and cash flows when firms have large book-tax differences. The Accounting Review, 80, 137-166. http://dx.doi.org/10.2308/accr.2005.80.1.137

Hoogendoorn, M. (1996). Accounting and taxation in Europe: A comparative overview. European Accounting Review, 5(4), 783-794. http://dx.doi.org/10.1080/09638189600000050

Joos, P., Pratt, J., \& Young, D. (2000). Book-tax differences and the value relevance of earnings. Working paper, Massachusetts Institute of Technology, Indiana University.

Lamb, M., Nobes, C. W., \& Roberts, A. D. (1998). International variations in the connections between tax and financial reporting. Accounting and Business Research, 28(3), 173-188. http://dx.doi.org/10.1080/00014788.1998.9728908

Micallef, M. (2011). The potential for tax influence on unconsolidated financial reporting in Malta: The similarity to the UK. Bank of Valletta Review, 44, 2-9.

Mills, L., \& Newberry, K. (2001). The influence of tax and non-tax costs on book-tax reporting differences: public and private firms. Journal of the American Taxation Association, 23, 1-19. http://dx.doi.org/10.2308/jata.2001.23.1.1

Nobes, C. (2004). A conceptual framework for the taxable income of businesses, and how to apply it under IFRS. Certified Accountants Educational Trust. London. Retrieved from http://www.accaglobal.com/documents/tech_tp_n03.pdf

Nobes, C. W., \& Schwenke, H. R. (2006). Modelling the links between tax and financial reporting: A longitudinal examination of norway over 30 years up to IFRS adoption. European Accounting Review, 15(1), 63-87. http://dx.doi.org/10.1080/09638180500510418

Oliveras, E., \& Puig, X. (2007). The changing relationship between tax and financial reporting in Spain. Accounting in Europe, 2(1), 195-207. http://dx.doi.org/10.1080/09638180500379020

Radcliffe, G. (1993). The relationship between tax law and accounting principles in the United Kingdom and France. Irish Journal of Taxation, 1, 1-20.

Radebaugh, L. (1975). Environmental factors influencing the development of accounting objectives, standards, and practices in Peru. International Journal of Accounting Education and Research, 11(1), 39-56.

Rossignol, J. L. (1999). Comptabilité et fiscalité: Chronique d'une relation «impérieuse». Comptabilité-Contrôle-Audit, 5(2), 5-24. http://dx.doi.org/10.3917/cca.052.0005

Rossignol, J. L. (2002). La politique fiscalo-comptable des entreprises françaises: Une étude exploratoire. $\begin{array}{llll}\text { Comptabilité-Contrôle-Audit, } & 8(1), & 89-110 . & \text { Retrieved }\end{array}$ http://www.cairn.info/article.php?ID_ARTICLE=CCA_081_0089

Shaviro, D. (2009). The optimal relationship between taxable income and financial accounting income: Analysis and a proposal. The Georgetown Law Journal, 97(2), 423-484. http://dx.doi.org/10.2139/ssrn.1017073

Tang, T. Y., \& Firth, M. (2011a). Can book-tax differences capture earnings management and tax management? Empirical evidence from China. The International Journal of Accounting, 46(2), 175-204. http://dx.doi.org/10.1016/j.intacc.2011.04.005

Tang, T. Y., \& Firth, M. (2011b). Earnings persistence and stock market reactions to the different information in book-tax difference: Evidence from China. The International Journal of Accounting, 47, 369-397. http://dx.doi.org/10.1016/j.intacc.2012.07.004

Whitaker, C. (2005). Bridging the book-tax accounting gap. The Yale Law Journal, 115(3), 680-726.

Wilson, R. (2009). An examination of corporate tax shelter participants. The Accounting Review, 84, 969-999. http://dx.doi.org/10.2308/accr.2009.84.3.969 


\section{Appendix A}

\section{Changes in the accounting-taxation links over time}

\begin{tabular}{|c|c|c|}
\hline period & Accounting and fiscal links & Major reforms affecting the report period \\
\hline 1956-1968 & $\begin{array}{l}\text { Accounting is governed by the } \\
\text { French chart of accounts. The } \\
\text { tax legislation did not undergo } \\
\text { radical change. No significant } \\
\text { difference between accounting } \\
\text { income and taxable income. } \\
\text { Accounting favors the state and } \\
\text { meets the requirements of the } \\
\text { latter for taxation. }\end{array}$ & $\begin{array}{l}\text { - Reforms in the tax system } \\
\text { - Raising taxes in } 1958 \\
\text { - Strengthening incentive schemes by the Act of } 10 \text { February } 1958 \\
\text { - Changes in structures of some taxes by the law of } 31 \text { December } 1962 \\
\text { - Establishment of a single income statement } 31 \text { December } 1962 \\
\text { - Exemption of profits and income reinvested by the law of } 31 \text { December } 1962 \\
\text { - Reforms in accounting } \\
\text { - Restructuring of the chart of accounts } 1947\end{array}$ \\
\hline 1968-1989 & $\begin{array}{l}\text { The development plan } \\
\text { accounting in } 1968 . \\
\text { Introduction of new tax rules } \\
\text { that favor the differentiation } \\
\text { between accounting income } \\
\text { and taxable income }\end{array}$ & $\begin{array}{l}\text { - Reforms in the tax system } \\
\text { - The institution of presumptive tax regime for the patent. } \\
\text { - Widespread and automaticity of financial deductions in } 1974 . \\
\text { - The merger of three fees in one multiple tax rates (VAT). } \\
\text { - Streamlining of some tax benefits to encourage savings and reduce the investment cost. } \\
\text { - Setting a ceiling for the amount of reinvested earnings in } 1976 . \\
\text { - Reforms in accounting } \\
\text { - The determination of the earning through successive stages. } \\
\text { - Introduction of the concept of intermediate balance of management and the concept of } \\
\text { Value Added Tax. } \\
\text { - Special Plan for SMEs. }\end{array}$ \\
\hline 1989-1993 & $\begin{array}{l}\text { Tax Reforms Broadening the } \\
\text { tax base and reducing tax } \\
\text { categories. The difference } \\
\text { between accounting income } \\
\text { and taxable income increases. }\end{array}$ & $\begin{array}{l}\text { - Reforms in the tax system } \\
\text { - Income tax and tax on personal income instead of the scheduled taxes and general taxes. } \\
\text { - The reduction of the tax on corporate profits by reducing it to } 35 \% \text { against } 65 \% \\
\text { previously. } \\
\text { - Articles } 47 \text { and } 48 \text { of Law } 89-114 \text { of } 30 \text { December } 1989 \text { specifying the method of } \\
\text { determining taxable income. }\end{array}$ \\
\hline 1993-1997 & Code investment incentives & $\begin{array}{l}\text { - Reforms in the tax system } \\
\text { - The freedom to invest, freedom to transfer profits abroad and the free transfer of capital at } \\
\text { the time of the project. } \\
\text { - Possibility to opt for accelerated depreciation method for equipment and production } \\
\text { equipment whose useful life of more than } 7 \text { years. }\end{array}$ \\
\hline $1997-2002$ & $\begin{array}{l}\text { Development of Tunisian } \\
\text { accounting system. Total } \\
\text { disconnection of accounting } \\
\text { regulations and tax regulations. }\end{array}$ & $\begin{array}{l}\text { - Reforms in the tax system } \\
\text { - Article } 79 \text { of Law } 97-88 \text { Finance Act for the year } 1998 \text { requires companies to join the } \\
\text { annual statements of income or profits of a state determination of taxable income. } \\
\text { - Reforms in accounting } \\
\text { - Presentation of rules, norms, conventions and the characteristic qualities of accounting } \\
\text { information. } \\
\text { - Approval of accounting system. }\end{array}$ \\
\hline $2002-2013$ & $\begin{array}{l}\text { Starting of the negative effects } \\
\text { of the disconnection between } \\
\text { the two normalizations } \\
\text { (accounting manipulation for } \\
\text { tax purposes ) }\end{array}$ & $\begin{array}{l}\text { - Reforms in the tax system } \\
\text { - Rejection of accounts by the tax authorities. } \\
\text { - The decrease in the tax on profits of companies which increased to } 30 \% \text { instead of } 35 \% \text {. } \\
\text { - Reforms in accounting } \\
\text { - Approval of accounting standards on consolidation (2003). } \\
\text { - Accounting Standard on Lease (2008) } \\
\text { - Other. } \\
\text { - Act on financial security (2005). }\end{array}$ \\
\hline
\end{tabular}




\section{Copyrights}

Copyright for this article is retained by the author(s), with first publication rights granted to the journal.

This is an open-access article distributed under the terms and conditions of the Creative Commons Attribution license (http://creativecommons.org/licenses/by/3.0/). 